\title{
Erratum to: Inter-ethnic differences in genetic variants within the transmembrane protease, serine 6 (TMPRSS6) gene associated with iron status indicators: a systematic review with meta-analyses
}

\author{
Wanjiku N. Gichohi-Wainaina ${ }^{1}$ - G. Wayne Towers ${ }^{2}$ - Dorine W. Swinkels ${ }^{3}$. \\ Michael B. Zimmermann ${ }^{4} \cdot$ Edith J. Feskens $^{1} \cdot$ Alida Melse-Boonstra ${ }^{1,5}$
}

Published online: 24 March 2015

(C) Springer-Verlag Berlin Heidelberg 2015

\section{Erratum to: Genes Nutr (2015) 10:442 \\ DOI 10.1007/s12263-014-0442-2}

After publication of this paper, the authors have determined that the forest plots presented are incorrect. Corrected fixed-effects forest plots are found below. However, the information in the text is correct except for the following two points: (1) under the subheading "Associations of rs4820268 with $\mathrm{Hb}$ and iron status", it should read that in Caucasian populations the $\mathrm{G}$ allele of rs 4820268 results in lower concentrations of $\mathrm{Hb}$ by $0.08 \mathrm{~g} / \mathrm{dL}(95 \% \mathrm{CI}-0.16$, $-0.01)$. In the "Discussion", based on our meta-analyses, the overall effect estimate of the Asian studies indicates that for each $\mathrm{G}$ allele of rs4820268 an additional decrease of 0.08 and 3.81 is observed for $\mathrm{Hb}$ and ferritin values, respectively (Figs. 2, 3, 4, 5, 6, 7, 8).

The online version of the original article can be found under doi:10.1007/s12263-014-0442-2.

Alida Melse-Boonstra

alida.melse@wur.nl

1 Division of Human Nutrition, Wageningen University, P.O. Box 8129, 6700 EV Wageningen, The Netherlands

2 Centre of Excellence for Nutrition, North-West University (Potchefstroom Campus), Potchefstroom, South Africa

3 The Laboratory of Genetic, Endocrine and Metabolic Diseases, Department of Laboratory Medicine, Radboud University Medical Centre, Nijmegen, The Netherlands

4 Laboratory of Human Nutrition, Institute of Food Nutrition and Health, Department of Health Sciences and Technology, Swiss Federal Institute of Technology, Zurich, Switzerland

5 Bomenweg 2, Bdg 307, 6703 HD Wageningen, The Netherlands 


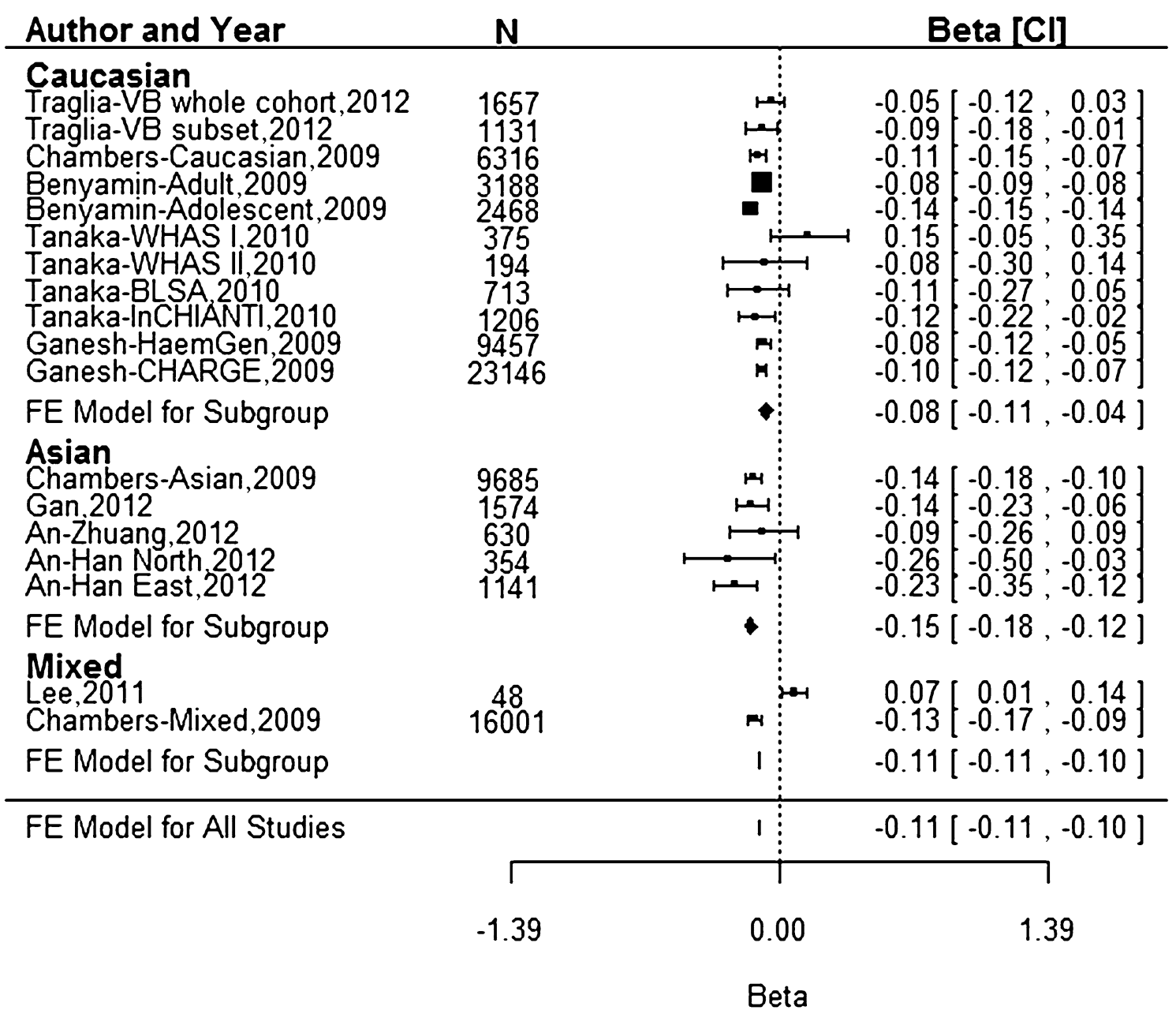

Fig. 2 Fixed-effects meta-analysis of observational studies evaluating association of rs855791 with haemoglobin concentration (g/dL) 


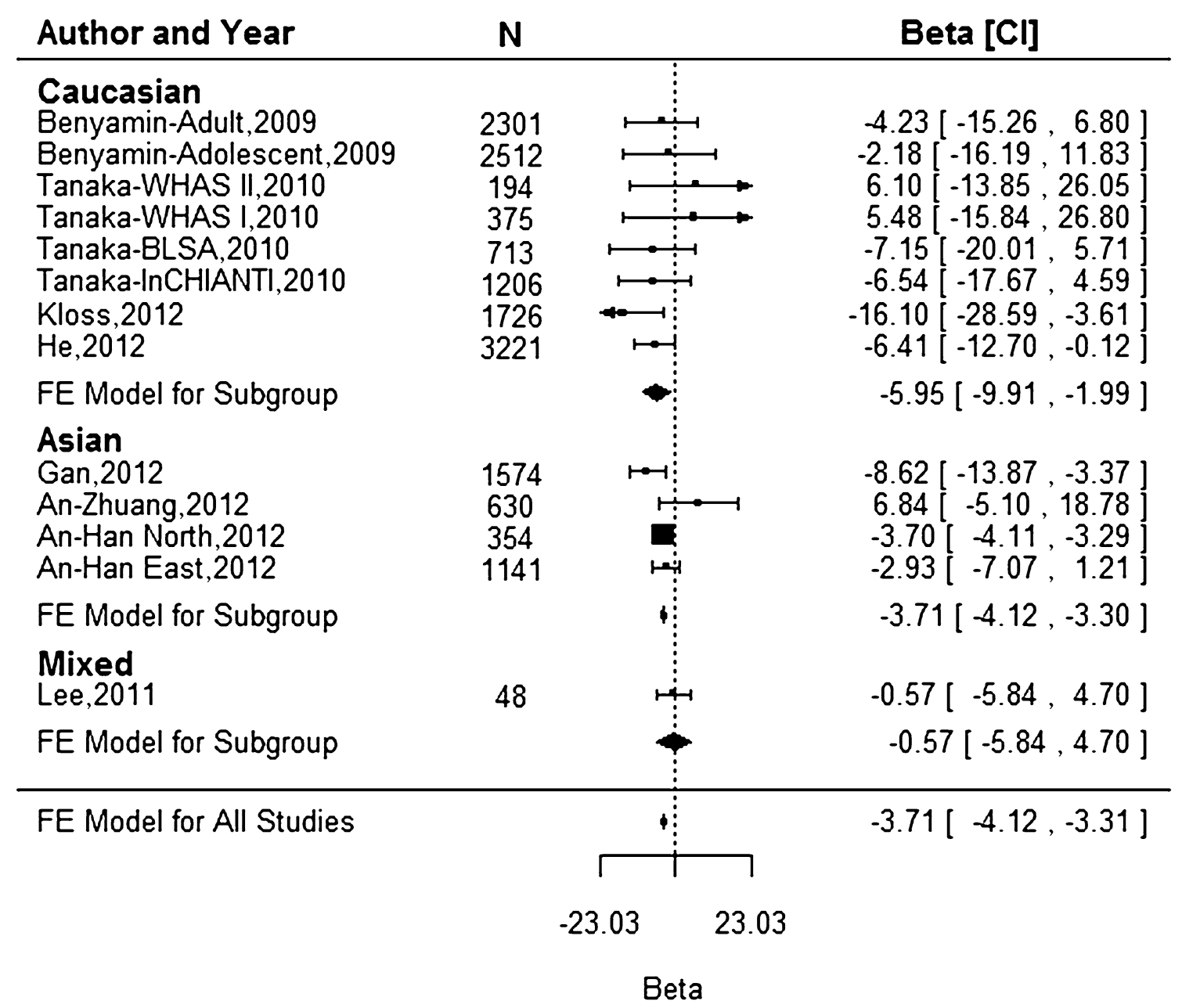

Fig. 3 Fixed-effects meta-analysis of observational studies evaluating association of rs855791 with ferritin $(\mu \mathrm{g} / \mathrm{L})$

Fig. 4 Fixed-effects metaanalysis of observational studies evaluating association of rs855791 with serum transferrin receptor $(\mathrm{mg} / \mathrm{dL})$

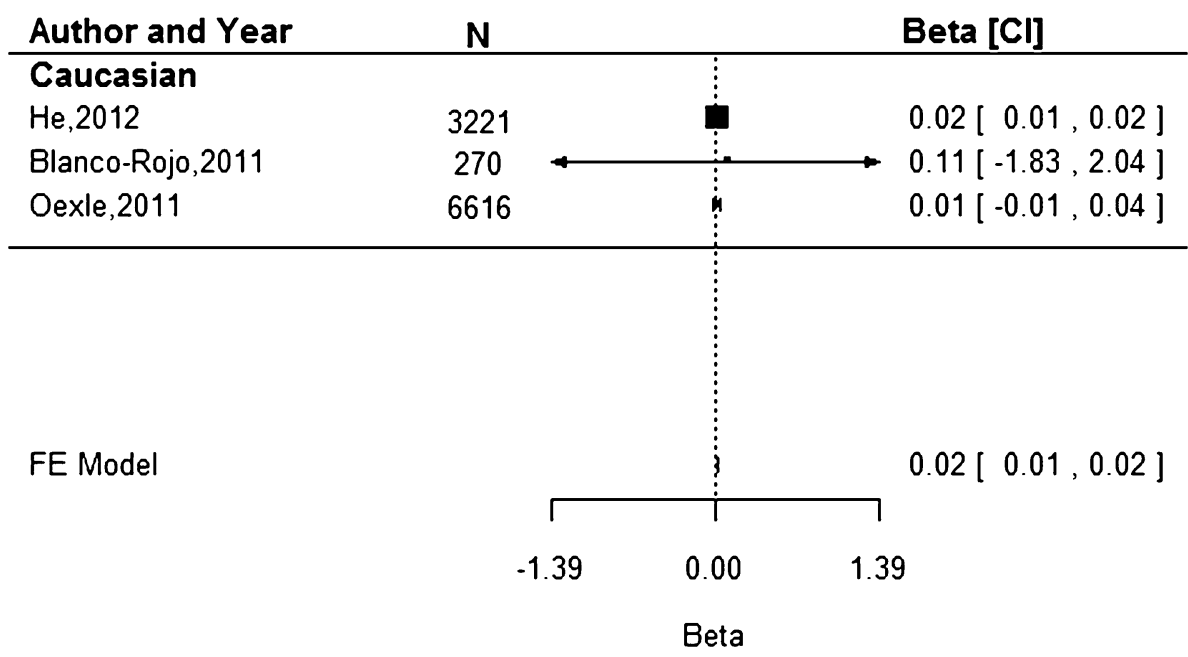


Fig. 5 Fixed-effects metaanalysis of observational studies evaluating association of rs855791 with with transferrin (mg/dL)

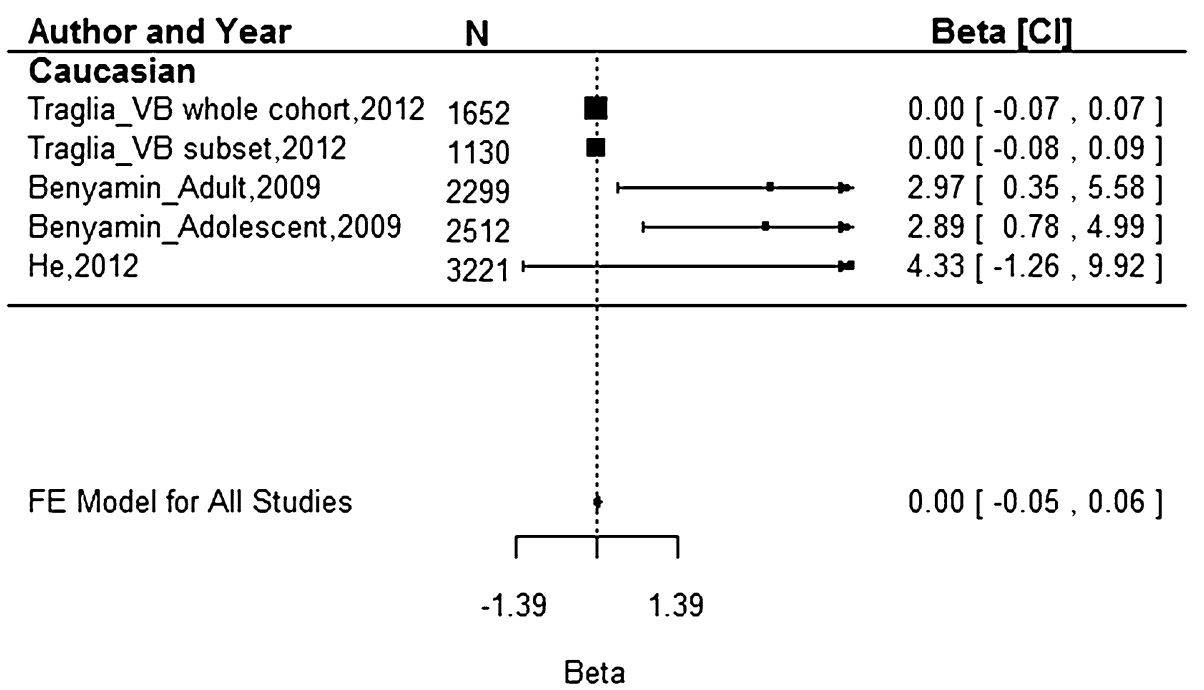

Fig. 6 Fixed-effects metaanalysis of observational studies evaluating association of rs4820268 with haemoglobin concentration $(\mathrm{g} / \mathrm{dL})$

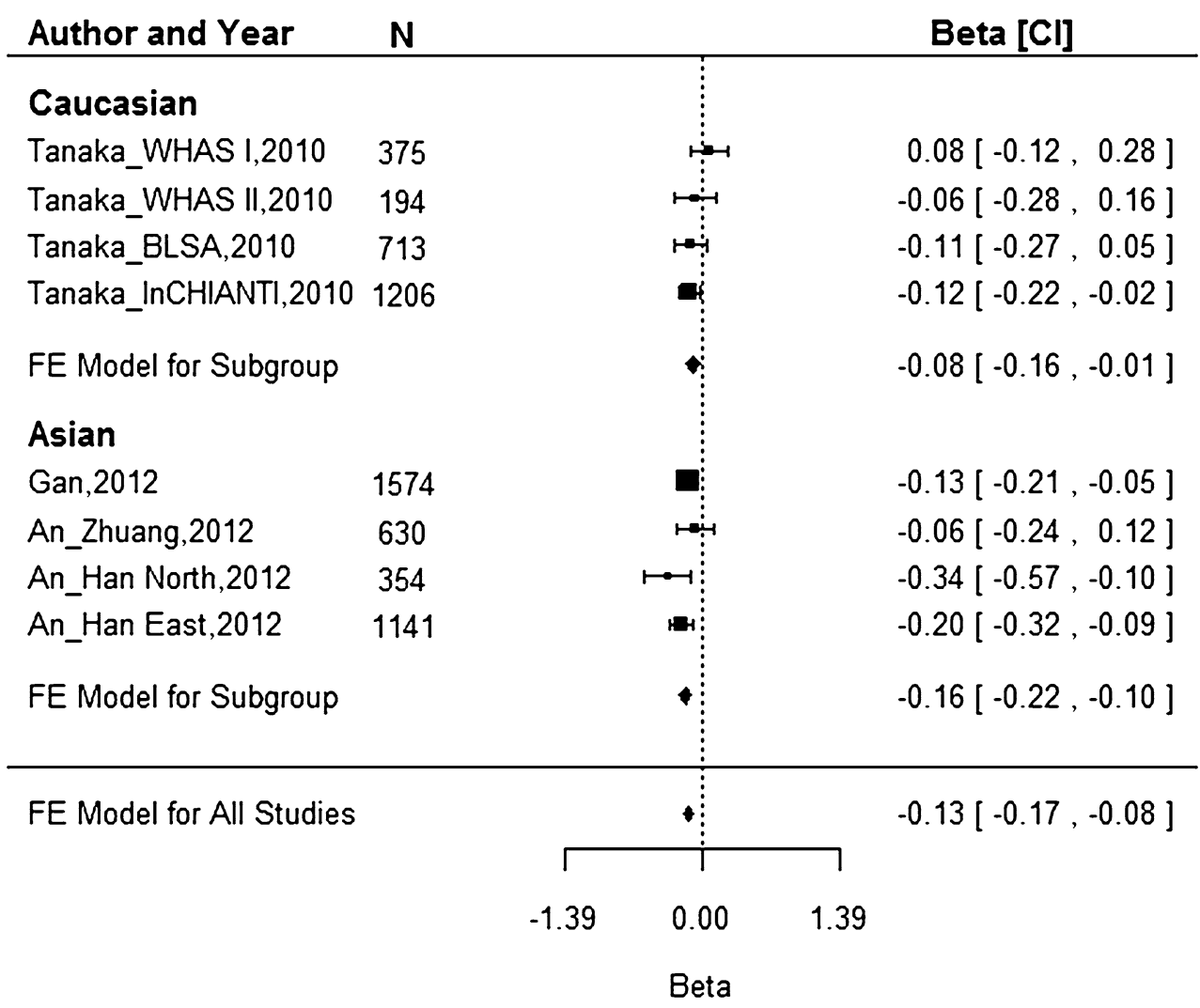


Fig. 7 Fixed-effects metaanalysis of observational studies evaluating association of rs4820268 with ferritin $(\mu \mathrm{g} / \mathrm{L})$
Fig. 8 Fixed-effects metaanalysis of observational studies evaluating association of rs4820268 with serum transferrin receptor $(\mathrm{mg} / \mathrm{dL})$

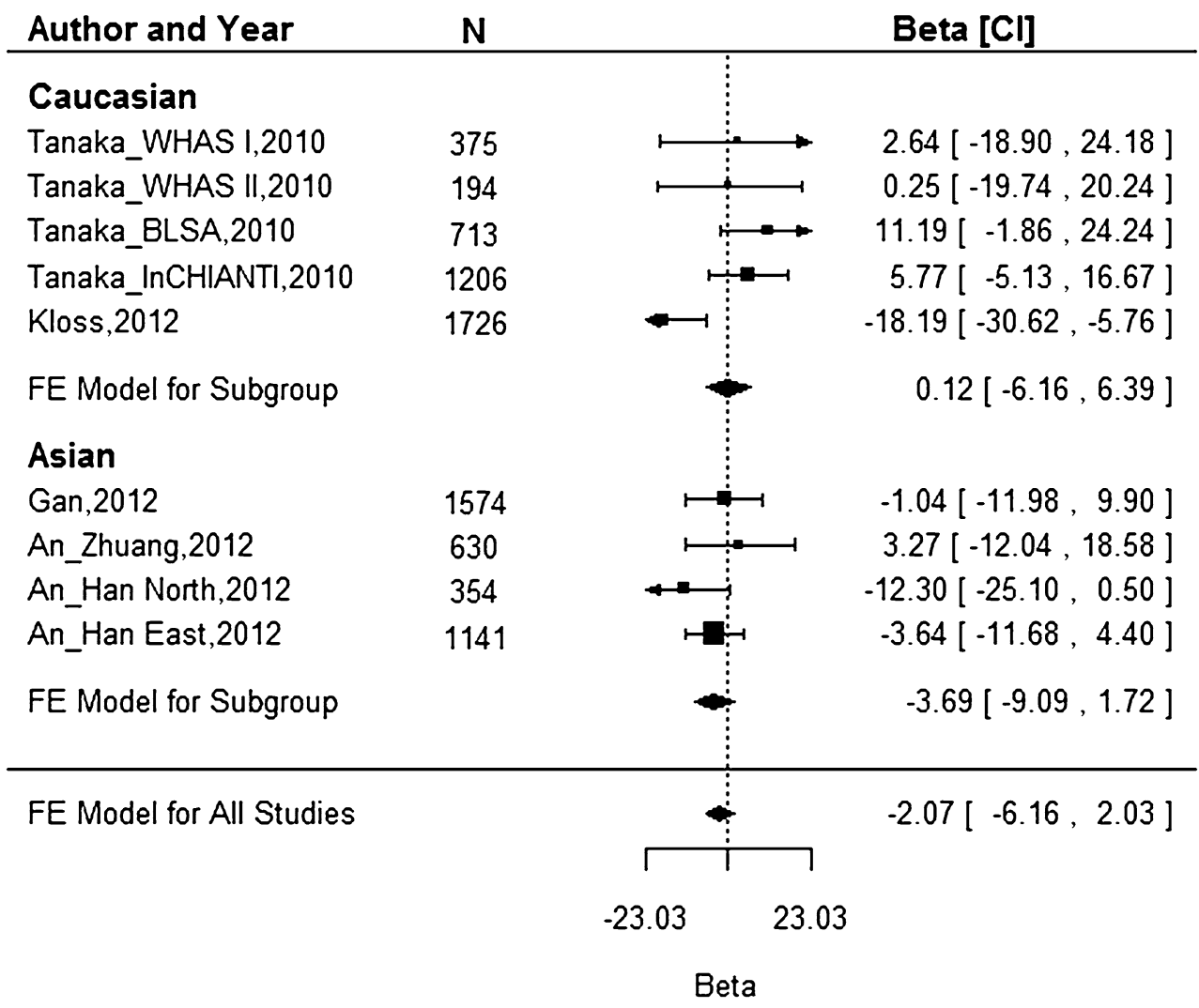

\begin{tabular}{|c|c|c|c|}
\hline Author and Year & $\mathbf{N}$ & & Beta [Cl] \\
\hline \multicolumn{4}{|l|}{ Caucasian } \\
\hline Oexle,2011 & 6616 & 口: & $-0.10[-0.13,-0.08]$ \\
\hline Pichler_InCHIANTI,2011 & 1181 & $\dot{m}$ & $-0.02\left[\begin{array}{ll}-0.06,0.02\end{array}\right]$ \\
\hline Pichler_MICROS,2011 & 1330 & ma & $-0.09[-0.13,-0.05]$ \\
\hline \multirow[t]{4}{*}{ FE Model } & & $\vdots$ & $-0.08[-0.10,-0.06]$ \\
\hline & $\Gamma$ & $i$ & 7 \\
\hline & -1.39 & 0.00 & 1.39 \\
\hline & & Beta & \\
\hline
\end{tabular}

